\title{
SMART GRID TECHNOLOGIES IN ELECTRIC POWER SUPPLY SYSTEMS OF PUBLIC TRANSPORT
}

\author{
Mikołaj BARTŁOMIEJCZYK* \\ Faculty of Electrical and Control Engineering, Gdansk University of Technology, Poland
}

Received 23 March 2017; revised 19 August 2017; accepted 16 September 2017

\begin{abstract}
Nowadays the issue of electric energy saving in public transport is becoming a key area of interest which is connected both with a growth in environmental awareness of the society and an increase in the prices of fuel and electricity. It can be achieved by improving the usage of regenerative breaking. In 2016 the Przedsiębiorstwo Komunikacji Trolejbusowej (PKT, Trolleybus Transport Company) in Gdynia began practical implementation of Smart Grid solutions within its trolleybus network. These activities constitute an element of the project ELIPTIC, realised by PKT within the scientific research fund Horizon 2020. The first stage of implementing intelligent network solutions was completed in 2016, and further activities are planned for the next few years. This paper presents a review of Smart Grid solutions which can be implemented in urban traction supply systems, describes the PKT experience concerning the implementation of Smart Grid solutions in trolleybus network supply system to date.
\end{abstract}

Keywords: trolleybuses, smart grid systems, energy recuperation, electric traction, traction substation, energy savings.

\section{Introduction}

Transport is responsible for almost $30 \%$ of the world's overall energy consumption. What is more, energy consumption is increasing, as the societies are becoming richer and the transport needs are growing. Hence it is necessary to start implementing technologies allowing for reduction of specific energy consumption (Falvo et al. 2011). Thanks to the development of power electronic drives and energy accumulation systems, such solutions have become available for electric vehicles (González-Gil et al. 2014). Recuperation of braking energy is one of the most promising solutions (González-Gil et al. 2013).

Any electrical machine is able to work in two directions of energy flow. In the case of traction motors, this means the possibility of generator operation during braking of the vehicle, involving the conversion of vehicle kinetic energy into electrical energy, thereby producing the braking torque (Jarzebowicz et al. 2017). This energy was at first dissipated in braking resistors located in the vehicle. The development of electric drive systems, especially high-power semiconductor drives, resulted in the spread of recuperation in trams and trolleybuses. It involves recuperation of electric energy during braking of the vehicle, and its re-use.
The growing number of trams and trolleybuses equipped with recuperation systems contributes to the increase in the amount of energy recovered during braking (Hamacek et al. 2014). However, the DC traction supply systems are characterised by a limited possibility to absorb recuperation energy, and, due to the one-direction flow of energy in traction substations, it is not possible to return the excess of recuperation energy into the surrounding power grid.

Traction supply systems are designed and constructed without taking into consideration the necessity to minimise transmission losses in the contact line and increase the effectiveness of energy recovery. The attention is focused on traction vehicles or on the effectiveness of energy generation and its distribution within public power grid. The majority of investments in urban transport to date is focused on the area of modernising the vehicles and implementation of modern technologies in electric public transport (Frilli et al. 2016). Numerous new technical solutions concerning the vehicles have been implemented during the last twenty years, for example induction traction motors, high-power converter systems and on-board energy storage devices. In contrast, supply systems are still

*Corresponding author. E-mail: mikolaj.bartlomiejczyk@pg.edu.pl 
based on technical ideas from the 1950s. Hence it is necessary at present to place the emphasis on developing modern technical solutions for power infrastructure of urban transport. Implementation of modern solutions in vehicles without simultaneous modernisation of supply systems will not bring the expected results (Bartłomiejczyk, Połom 2016).

Contemporary urban overhead line power supply systems consist of many elements: traction substations, vehicles, energy banks, vehicle charging stations, remotelycontrolled overhead line disconnectors. Thus, it becomes necessary to provide an adequate structure of urban overhead line power supply systems that would enable optimal use of all elements of the power system and ensure synergy between the individual elements. Accordingly, the municipal power supply systems become the dissipated energy networks with many sources of power supply, receptions of a different nature and the possibility of dynamic reconfiguration. Therefore, it becomes necessary to apply the Smart Grid technologies used in the commercial power industry (Díez, et al. 2012).

There is no universally accepted definition of Smart Grid. The term "Smart Grid" refers to numerous, often simple technical solutions which, together, may change the structure and improve efficiency of the functioning of power system. Smart Grid is an intelligent network, which incorporates a lot of elements cooperating with each other (Tuballa, Abundo et al. 2016).

Thanks to Smart Grid solutions an electric traction supply systems is no longer a passive energy receiver; it becomes a dynamic link of the power system. The power system of public transport may play an active role in creating power islands, which constitute an element of modern intelligent power systems. That is why it is necessary to develop the possibilities of recuperation energy flow in the supply system.

Electric vehicles may be charged from renewable sources and thus become a fully ecological means of transport (Pearre, Swan 2016). Photovoltaic installation may be the main source of renewable energy used to drive vehicles, but it is also possible to apply other sources, such as, for example, mini co-generation (Angrisani et al. 2015). Energy recovered during braking, which may also be regarded as energy obtained from renewable sources is another source of energy for charging vehicles. In urban infrastructure it is also possible to use recuperative braking energy in many different ways, thus reducing electrical energy consumption. One of the possible recipients are administration buildings, which may become elements of an intelligent power system, actively adjusting their energy demand based on their needs or an element of local Smart Grid platforms. The overhead DC contact line used by tramways, trolleybuses or underground trains can be the means of joining the elements of a mini Smart Grid system in a city (Jiang et al. 2014).

The mini Smart Grid system based on recuperation energy generated in urban traction vehicles has been pro- posed and described by Jiang et al. (2014). The majority of braking energy is generated within station areas; therefore it is possible to utilise it for the purpose of supplying station facilities, such as lighting, ventilation, airconditioning, escalators. The cooperation of DC traction supply system and the AC network occurs at the level of low voltage installations, which significantly simplifies the system construction and makes it possible to avoid the necessity of connecting it to high voltage network. The detailed simulation analysis of such Smart Grid system has been presented by Nasr et al. (2014). That system was extended by adding charging stations for electric cars and a recuperation energy storage device used to level off momentary peaks of recuperation energy generation. The presented works are theoretical in their character.

This paper presents possibilities of increasing utilisation of recuperation energy by applying subsequent Smart Grid solutions. The assessment of possibilities for further increase of recuperation energy utilisation thanks to intelligent network solutions was performed based on research works conducted within the ELIPTIC programme (GlotzRichter, Koch 2016).

\section{The structure of the power supply systems of municipal electric traction and Smart Grid technologies in municipal overhead line power supply systems}

It is an important issue to ensure the conditions for the use of electricity generated during braking. In the classic supply system, where substations are not equipped with the energy-storing devices, the flow of recuperative braking current may take place in two ways (Bartłomiejczyk, Połom 2017):

- in the path: vehicle - overhead line - vehicle, when the braking vehicle and accelerating vehicle are in the same power supply section;

- in the path: vehicle - overhead line - feeder - busbars of the traction substation - feeder - overhead line - vehicle, when the vehicles are in two power supply sections.

In both cases, the recuperation energy is absorbed by the second vehicle in the power supply section able to accept the energy, i.e. the vehicle is in motion. However, in common situations in the power supply areas, there are no vehicles able to absorb the energy. Then the recuperation energy is dissipated in the braking resistors. One of the ways to increase the use of regenerative braking is to apply the Smart Grid intelligent network technologies.

In a classic electric traction supply system, energy flows from a traction substation through power supplies and contact line to vehicles, whereas in a Smart Grid power system a number of generating sources operate simultaneously (Altmann, Elschner 2009). These sources are mainly vehicles with recuperative braking; electrical energy may also be supplied by electrical energy storage devices and local generating sources (e.g. photovoltaic power stations). 
The application of Smart Grid technology makes it possible for this energy to flow to vehicles, and also allows for controlling the power flow distribution (Hewings, Palfreyman 2013). Table 1 presents the comparison of Smart Grid solutions for urban traction.

As it has been presented in Table 1, construction of energy storage devices and equipping traction substations with inverters is connected with substantial costs. The solution which can be applied at a low cost, and which, despite this, is not very common, is bilateral supply of the overhead contact line. It allows for flow of recuperation energy; furthermore, this energy can be used not only by other vehicles, but also for the purpose of charging electric buses. Charging stations for electric buses may constitute the second important element of intelligent supply systems for urban traction. It allows for obtaining the effect of synergy thanks to linking different electric traction systems. An additional solution, which is easy to realise, are stationary DC/AC converters, returning the unused recuperation energy to low voltage network of public buildings, where it can be consumed for own needs of these buildings. A simplified diagram of the supply system with bilateral contact line supply, bus charging and mini inverter stations has been presented in Figure 1.

Table 1. Smart Grid solutions in urban electric traction

\begin{tabular}{|c|c|c|c|}
\hline Solution & Aim & Cost & Limitations and barriers \\
\hline $\begin{array}{l}\text { Charging stations for electrical buses } \\
\text { and cars supplied from the catenary } \\
\text { (Díez et al. 2012) }\end{array}$ & $\begin{array}{l}\text { using recuperation energy for electric } \\
\text { vehicles charging; } \\
\text { reducing the costs of constructing the } \\
\text { charging station }\end{array}$ & $\mathrm{M}$ & $\begin{array}{l}\text { potential location of charging station } \\
\text { outside the contact line; } \\
\text { limited charging power resulting from } \\
\text { the parameters of contact line }\end{array}$ \\
\hline $\begin{array}{l}\text { Remote control of the disconnectors } \\
\text { system in the catenary }\end{array}$ & $\begin{array}{l}\text { enabling immediate reconfiguration of the } \\
\text { power supply of the overhead contact line } \\
\text { in the case of damage }\end{array}$ & $\mathrm{M}$ & \\
\hline $\begin{array}{l}\text { Smart protection devices (Niemann } \\
\text { et al. 2007) }\end{array}$ & $\begin{array}{l}\text { allows for detection of damage in overhead } \\
\text { contact line from remote network systems }\end{array}$ & $\mathrm{L}$ & \\
\hline $\begin{array}{l}\text { Stationary and vehicle energy banks: } \\
\text { supercapacitors, storage energy } \\
\text { systems (Bartłomiejczyk, Połom 2016) }\end{array}$ & $\begin{array}{l}\text { collecting the unused recuperation energy } \\
\text { for re-use }\end{array}$ & $\mathrm{H}$ & \\
\hline $\begin{array}{l}\text { Traction substation inverters to return } \\
\text { recuperated energy to AC supply } \\
\text { network (Cornic 2010) }\end{array}$ & $\begin{array}{l}\text { return of unused recuperation energy into } \\
\text { the AC supply network }\end{array}$ & $\mathrm{H}$ & $\begin{array}{l}\text { lack of interest in purchasing } \\
\text { recuperated energy by energy } \\
\text { suppliers }\end{array}$ \\
\hline $\begin{array}{l}\text { Traction stationary mini-inverters } \\
\text { to return recuperated energy to low } \\
\text { voltage AC network, for own needs } \\
\text { (Nasr et al. 2014) }\end{array}$ & $\begin{array}{l}\text { return of unused recuperation energy } \\
\text { into the AC low voltage network, for own } \\
\text { needs, e.g. to be utilised in administration } \\
\text { buildings located within the area covered } \\
\text { by the overhead contact line }\end{array}$ & $\mathrm{L}$ & $\begin{array}{l}\text { lack of producers of ready-made } \\
\text { technical solutions }\end{array}$ \\
\hline $\begin{array}{l}\text { Bilateral supply of the contact line } \\
\text { (Bartłomiejczyk, Połom 2017) }\end{array}$ & $\begin{array}{l}\text { reduction of voltage losses in overhead } \\
\text { contact line; } \\
\text { increased utilisation of regenerative } \\
\text { braking }\end{array}$ & $\mathrm{L}$ & $\begin{array}{l}\text { very rarely applied in urban traction } \\
\text { due to the reluctance of technical } \\
\text { service staff }\end{array}$ \\
\hline $\begin{array}{l}\text { Local supply sources attached to } \\
\text { contact line, e.g. photovoltaic power } \\
\text { stations (Díez et al. 2012) }\end{array}$ & $\begin{array}{l}\text { increased utilisation of renewable energy } \\
\text { sources; } \\
\text { local strengthening of the supply system }\end{array}$ & $\mathrm{H}$ & \\
\hline
\end{tabular}

Notes: $\mathrm{H}$ - high, $\mathrm{M}$ - middle, $\mathrm{L}$ - low.

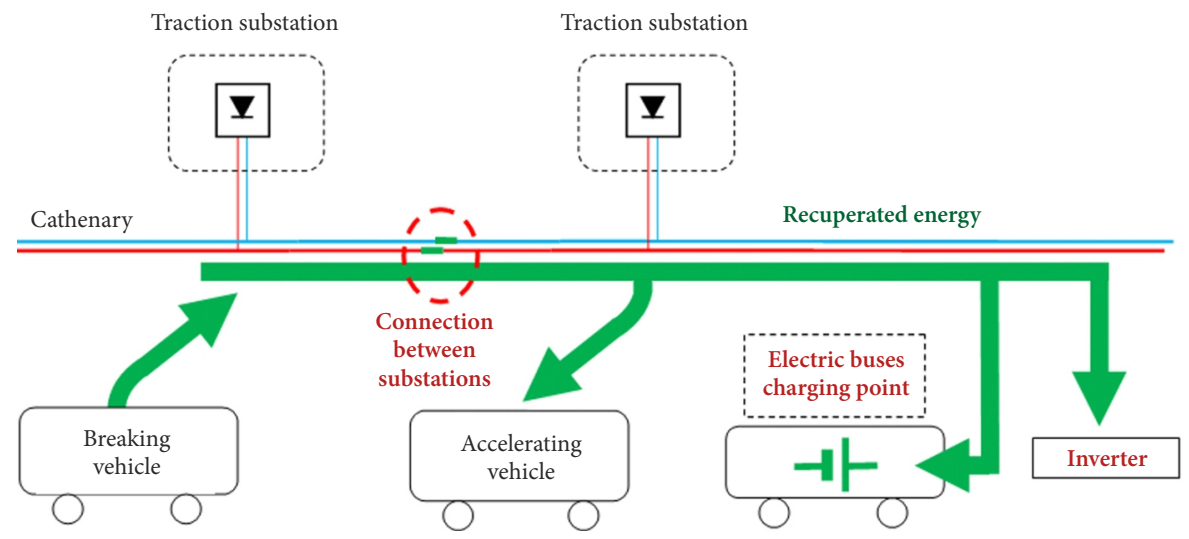

Figure. 1. Diagram of recuperation energy flow between braking vehicle and accelerating vehicle in bilateral contact line supply system, together with electric buses charging point 


\subsection{Bilateral supply of contact line}

In a classic supply system each of the contact line sections is supplied solely from one substation, so the supply areas of individual substations are galvanically separated from each other. In the case of low traffic intensity or small substation areas, there may occur a situation where there is no vehicle which could absorb the recuperation energy from a braking vehicle. Then this energy will be dissipated in braking resistors. However, it is possible to increase the possibility of finding a recipient of the generated energy by joining the supply area with the neighbouring substation, thus allowing for the flow of recuperation energy to the area of that neighbouring substation. Such a situation has been presented schematically in Figure 1 .

An important issue relating to the implementation of bilateral power supply in traction supply system is to ensure effective breaking capacity. In the case of long power sections supplied from two substations, there may be a situation where short-circuit current is too low for effective switching of a protection device. This causes low popularity of bilateral power supply in municipal transport power systems. However, technology of modern protection devices can solve this problem. It is now possible to equip traction substations with time-current protections and differential protections, which help to locate even the distant short-circuits in the overhead line. Those protections may be connected by means of GSM network with a remotely-controlled overhead line disconnectors which, in the case of detecting a short-circuit and its interruption, automatically reconfigure the supply system. This allows for reduction of the area without power in the event of damage to the overhead line.

\subsection{Using tramway and trolleybus infrastructure for charging electric buses}

Charging electric buses requires supply with considerable power, which is why it seems justified, in the case of operators exploiting both tramway and trolleybus networks, to use contact line supply systems for the functioning of electric buses. Such solution makes it possible to increase the recovery of braking energy by utilising it in charging electric buses. Moreover, in such a situation it is not necessary to build lines supplying charging points from the public power grid, which reduces the costs and simplifies the construction process. Construction of a power supply line for high-speed charging, in many cases, has numerous technical constraints, such as related to the limited power available in the grid (Bartłomiejczyk, Połom 2017). As a result, the synergy effect connected with co-functioning of various electric traction systems is obtained.

One of the key issues connected with supplying electric buses from the tramway or trolleybus contact line is protection against electric shock. The body of an electric bus is insulated from the ground, which, in case of damaging the electrical installation and breakdown of voltage onto the vehicle construction creates the danger of electric shock in the course of connecting the bus to the supply network. This problem does not occur with regard to trolleybuses, as these vehicles possess a two-level insulation of the electrical installation. On the other hand, electric buses, due to reduced construction costs, possess only one level insulation of electrical installation, which results in additional safety requirements for charging systems. This is why the charging systems for electric buses can be divided as follows:

- taking into consideration the connection of an electric bus to the contact line - into galvanically separated and non-separated systems;

- taking into consideration the grounding of a vehicle which is being charged - into the systems where a vehicle is grounded during charging (i.e. three-, four- and five-wire systems) and systems without grounding. Connection of the above criteria makes it possible to create four versions of a system for charging electric buses from the overhead contact line (Table 2):

- charging electric buses in a two-wire system. This is the easiest charging method; a vehicle is supplied by direct connection to a $600 \mathrm{~V}$ contact line, which is performed with the use of a collector, without any additional wires. The main problem connected with this charging system is lack of galvanic separation between the overhead contact line and the electrical system of the bus. In the course of charging an electric bus there is a danger that passengers may receive an electric shock if the insulation is damaged;

- charging electric buses in a two-wire separated system, where it is necessary to use a charging converter, in order to ensure galvanic separation between the contact line and the electrical installation of the bus. Such a converter may also function as a converter for battery charging, which simplifies the vehicle equipment and reduces the cost of its production;

- charging electric buses in a four-wire system. The disadvantage of two-wire systems is lack of grounding of the electric bus construction during charging. It results in the danger of electric shock and, due to that, such a solution cannot be applied in many countries, for legal reasons. In a four-wire charging system the four-wire connection between an electric bus and a charging point consists of two charging wires, a grounding wire and a control wire, the latter controlling the state of grounding and stages of the charging process. In two-wire systems connection to a charging point is performed with the use of a collector, whose construction resembles that of a tramway pantograph. In a four-wire system a special connector is used;

- charging electric buses in an insulated four-wire system, which is similar to a standard four-wire charging system. It is distinguished by application of a separating DC/DC converter, which ensures galvanic insulation between the overhead contact line and the electric bus, thus increasing the level of safety. 
Table 2. Comparison of the presented charging systems

\begin{tabular}{|c|c|c|c|}
\hline & \multicolumn{2}{|c|}{ Connection with overhead contact line } \\
\hline & & Direct & Galvanic separation (DC/DC converter) \\
\hline \multirow{2}{*}{ 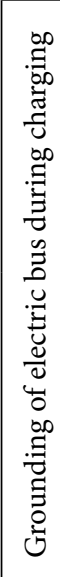 } & ż & $\begin{array}{l}\text { Two-wire system: } \\
\text { - very low investment costs; } \\
\text { - increased costs of vehicle - a necessity to install the } \\
\text { entire charging system (converter) in every vehicle; } \\
\text { - no possibility to charge a bus with passengers aboard; } \\
\text { charging can be performed only at end stops. } \\
\text { Used in: Vienna, Austria }\end{array}$ & $\begin{array}{l}\text { Two-wire system with galvanic separation: } \\
\text { - fully functional charging system, as in the case of the } \\
\text { standard electric bus system; } \\
\text { - high costs connected with construction of charging stations. } \\
\text { Used in: Prague, Czech Republic }\end{array}$ \\
\hline & 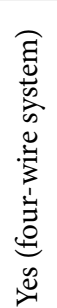 & $\begin{array}{l}\text { Four-wire system: } \\
\text { - fully functional charging system, as in the case } \\
\text { of the standard electric bus system; } \\
\text { - more complex pantograph tan in the case of two-wire } \\
\text { charging. } \\
\text { Used in: Dresden, Germany }\end{array}$ & $\begin{array}{l}\text { Four-wire system with galvanic separation: } \\
\text { - fully functional charging system, as in the case of the } \\
\text { standard electric bus system; } \\
\text { - the safest charging system with regard to protection against } \\
\text { electric shock; } \\
\text { - high costs - it is necessary to construct a charging } \\
\text { converter. } \\
\text { Used in: Lublin, Poland }\end{array}$ \\
\hline
\end{tabular}

Table 2 presents the comparison of the three charging systems for electric buses with the use of tramway or trolleybus infrastructure, which have been described above.

\subsection{Mini traction stationary inverters}

Conversion of unused recuperation energy into AC energy is, from the technical point of view, one of the easiest ways of utilising this energy. However, most of energy suppliers are not interested in receiving recuperation energy, due to the unpredictable character of its generation (Kolář et al. 2012). An alternative solution is to use this energy to a small extent, for own needs of urban municipal buildings, e.g. public buildings. Such buildings are characterised by electrical power consumption at the level of $50 \ldots 100 \mathrm{~kW}$, which value is similar to average generation of trolleybus recuperation power during braking. Connecting electrical installation in the buildings with the overhead contact line may be performed using inverters with the power of about $100 \mathrm{~kW}$ and galvanic isolation. Such inverters can be controlled by way of hysteresis, depending on the contact line voltage, which has been presented in Figure 2.

\subsection{Adjusting the off-load voltage of traction substations and using controlled traction rectifiers in substation}

The effectiveness of energy recovery, in particular in a bilateral contact line supply system, depends on the level of voltage in the contact line. When the upper value of regenerative braking threshold is exceeded, a braking resistor is activated and braking effectiveness is reduced (Figure 3).

The operation of a supply system in the course of recuperation can be considered as parallel connection of two voltage sources, each with different voltage. The source with the higher voltage is loaded to a higher degree, which degree depends on the relations between source voltages and their inner resistances. In the case of traction supply

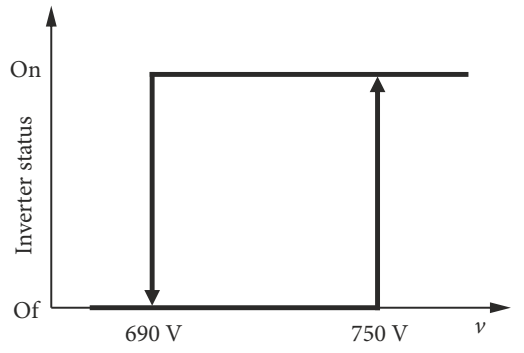

Figure 2. Inverter DC/AC command, $v$ - catenary voltage

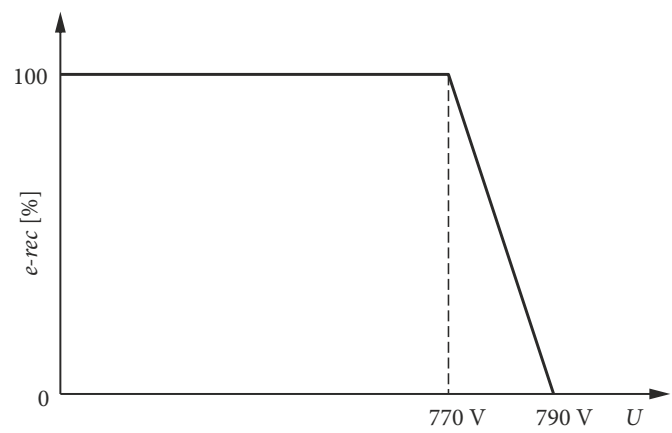

Figure 3. Characteristics of recovery efficiency e-rec in the function of catenary voltage $U$

systems, traction substations constitute one source, while the recuperating vehicles are the second one. As a result, the effectiveness of recuperation depends on the value of voltage in the supply system and the regenerative braking threshold of vehicles. The value of voltage in the supply system is dependent, to a great extent, on the idling voltage level of traction substations. The upper voltage threshold of regenerative braking assumed for the calculations is $770 \mathrm{~V}$. The increase of voltage in substation busbars results in the increase of substation load and, consequently, a decrease in regenerative braking effectiveness. If the idling voltage of traction substations exceeds the upper voltage 
threshold of regenerative braking, the level of energy recuperation falls to zero. Analogously, the effectiveness of energy recovery increases together with the increase of the upper voltage level of regenerative braking.

The effectiveness of regenerative braking may be increased by:

- increasing the upper voltage threshold of regenerative braking. The maximum value of this voltage is limited by the resilience of devices supplied by traction voltage and is at the level of $750 \ldots 800 \mathrm{~V}$ in the case of $600 \mathrm{~V}$ supply system;

- reducing the idling voltage of traction substation busbars. If this voltage is reduced too much, it may lead to insufficient supply voltage at these points of the contact line which are located far from the substation. Therefore, at rated load, the voltage in traction substation busbars should not be lower than $660 \mathrm{~V}$.

The limit values of recuperation voltage threshold and traction substation idling voltage threshold are restricted by voltage drops occurring in the contact line and may be modified only to a certain extent. An alternative solution is to use controllable rectifiers.

Due to the external characteristics of rectifier units (Figure 4) the substation idling voltage is higher, by approximately $60 \mathrm{~V}$, than the voltage at the rated load, and is usually at the level of $720 \mathrm{~V}$. Reduction of this voltage is possible by using rectifier units with lower inner resistance and more rigid characteristics. An alternative solution is to use controlled rectifiers with flat external characteristics.

\subsection{Energy management system}

Controlling the elements comprising the system of transforming recuperation energy is performed based on the value of contact line voltage (Figure 5). The most effective utilisation of recuperation energy is to give it to other vehicles, which are the most important recipient of the recovered energy. The energy intake by vehicles depends on the voltage in the overhead contact line only to a small degree, as recuperation energy is consumed by them within the whole range of voltage changeability in the contact line. Charging points for electric buses are the second recipient of energy. In order to increase utilisation of recuperation energy by charging points, particularly in the situation where there are no other recipients, it is necessary to apply short-term increase (by 50\%) of the battery charging current in vehicles at the time when the level of catenary voltage exceeds $690 \mathrm{~V}$. The inverter systems used to return recuperated energy for own needs of buildings should be used as the last ones; therefore they are switched on when the catenary voltage exceeds the threshold of $750 \mathrm{~V}$.

\section{Case study - introduction of Smart Grid system into Gdynia trolleybus network}

Gdynia is a port city on the Baltic Sea with the population of 250000. In 1943, its trolleybus network was put into operation and gradually developed, later to become the largest in Poland. Gdynia trolleybus carrier, Przedsiębiorstwo

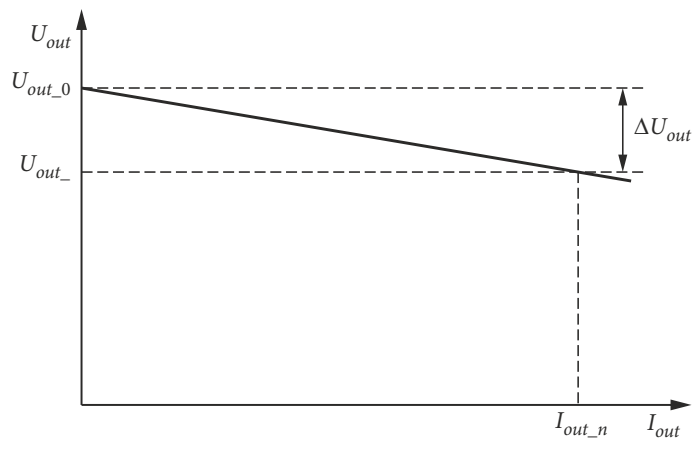

Figure 4. Simplified external characteristics of traction substation $\left(I_{\text {out } \_n}-\right.$ rated current of traction substation)

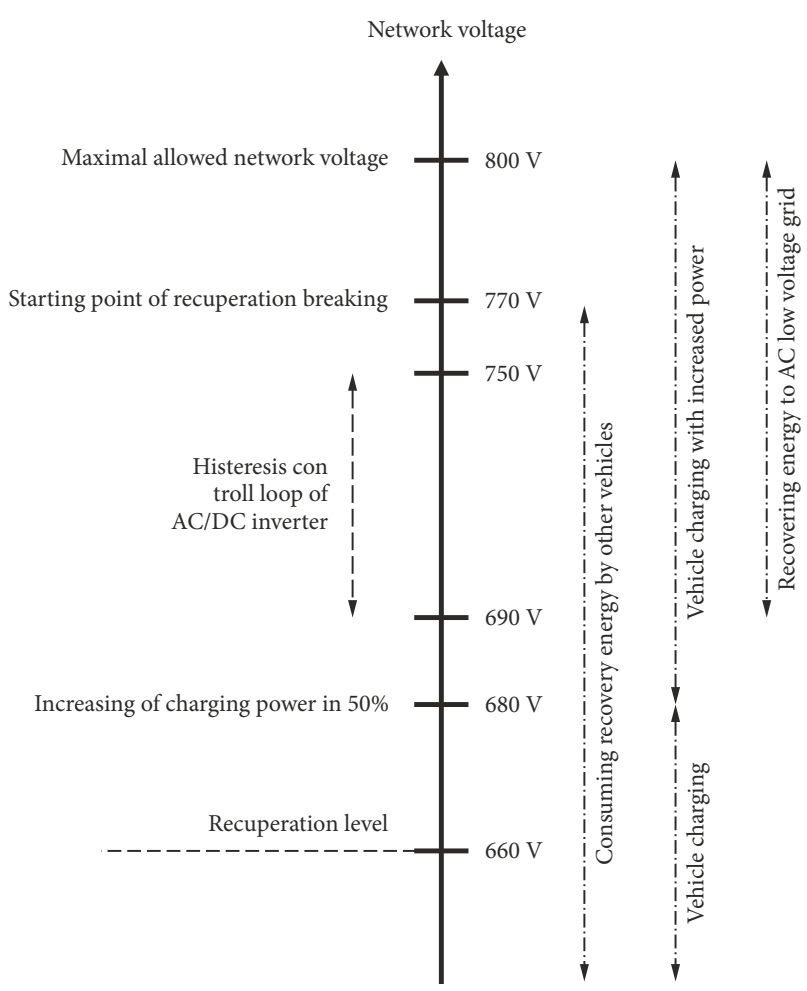

Figure 5. Voltage levels for control of elements of Smart Grid system

Komunikacji Trolejbusowej (PKT, Trolleybus Transport Company), currently operates a fleet of 85 trolleybuses on 12 service routes within a network whose length is almost $50 \mathrm{~km}$. Gdynia trolleybus network is powered from 10 traction substations in a unidirectional supply system. The traction substations differ with respect to the size of areas to which electricity is supplied and the number of rectifier sets, each substation powering $1 . . .6$ sections. Gdynia trackless trolleys consume nearly $10 \mathrm{GW} \cdot \mathrm{h}$ of electrical energy per year and are considered to be one of the biggest energy consumers in the city. Therefore, one may reasonably expect that some steps towards reducing power consumption would be appropriate (Połom, Palmowski 2009).

The neighbouring city of Sopot is a well-known Polish sea resort. A suburban trolleybus route Gdynia-Sopot, which is currently the only intercity trolleybus route in Poland, was built in 1949 (Połom, Bartłomiejczyk 2011). 
The section located within the area of Sopot is supplied from two traction substations Sopot I and Sopot II. The city of Sopot, due to its character of a spa, is planning to introduce electric buses into operation. Due to the low frequency of trolleybus service on the suburban route Gdynia-Sopot, recuperation of braking energy is utilised to a small degree. Currently only about $8 \%$ of energy is recovered. Moreover, the supply system within the area of Sopot was modernised in the years $2010 \ldots 2012$ and is now characterised by high installed power, which is utilised to a small extent. Therefore it is justified to use the trolleybus network for the purpose of charging electric buses, which would bring the following benefits:

- increasing the extent of braking energy recuperation - braking energy would be used to charge electric buses;

- increasing utilisation of modernised traction substations;

- due to wholesale purchase of electrical energy by PKT Gdynia, the energy used for charging buses would be cheaper when collected from the trolleybus network than it would be when purchased individually.

Additionally, it will be suggested that regenerative braking energy is used to supply public buildings located in the city centre. For this purpose, the analysis of operation of an inverter with the power of $50 \mathrm{~kW}$ will be performed.

In order to facilitate the flow of recuperation energy of vehicles and increase the recovery rate, introduction of bilateral supply between the substations Sopot I and Sopot II has been suggested. The anticipated supply system has been presented in Figure 6 .

The simulation of public transport supply system service was conducted using the Monte Carlo (Bartłomiejczyk, Połom 2017) method. The Monte Carlo method is based on the continuous repetition of a statistical experiment, which performs an analysis of the condition of the object using random input factors (Judek, Skibicki 2009; Hrbac et al. 2015; Nicolau et al. 2018; Kulesz 2005).

The result is a distribution of probability of the output variable. The simulation model is based on the following input data:

- trolleybus timetables;

- deviations in the implementation of timetables that are designated using studies of punctuality of public transport conducted by Zarzad Komunikacji Miejskiej in Gdynia;

- trolleybus velocity profile - the relationship between the expected speed of vehicles and their location,

- traction characteristics of trolleybuses.

A histogram of the probability of the number of vehicles located within a power supply section at the same time was established using timetables and deviations from their implementation. The velocity profile, i.e. the relationship between the location of vehicle $s$ and its expected velocity $v(s)$ was the basis for determining the probability distribution of the location of individual vehicles along the power supply section. This probability $p(s)$ was inversely proportional to the expected velocity at a given location. The operating status of the drive unit and then the trolleybus current were determined using the derivative of the velocity profile. The currents and voltages in the power supply system were calculated iteratively using the nodevoltage analysis until reaching the convergence of voltages $V$ in the calculation model. Figure 7 provides a simplified diagram of the simulation model.

It was assumed that the exploited trolleybuses would be Solaris Trollino $12 \mathrm{AC}$, equipped with traction engines with the power of $175 \mathrm{~kW}$. With regard to power, the situation where charging of buses is continuous, i.e. where

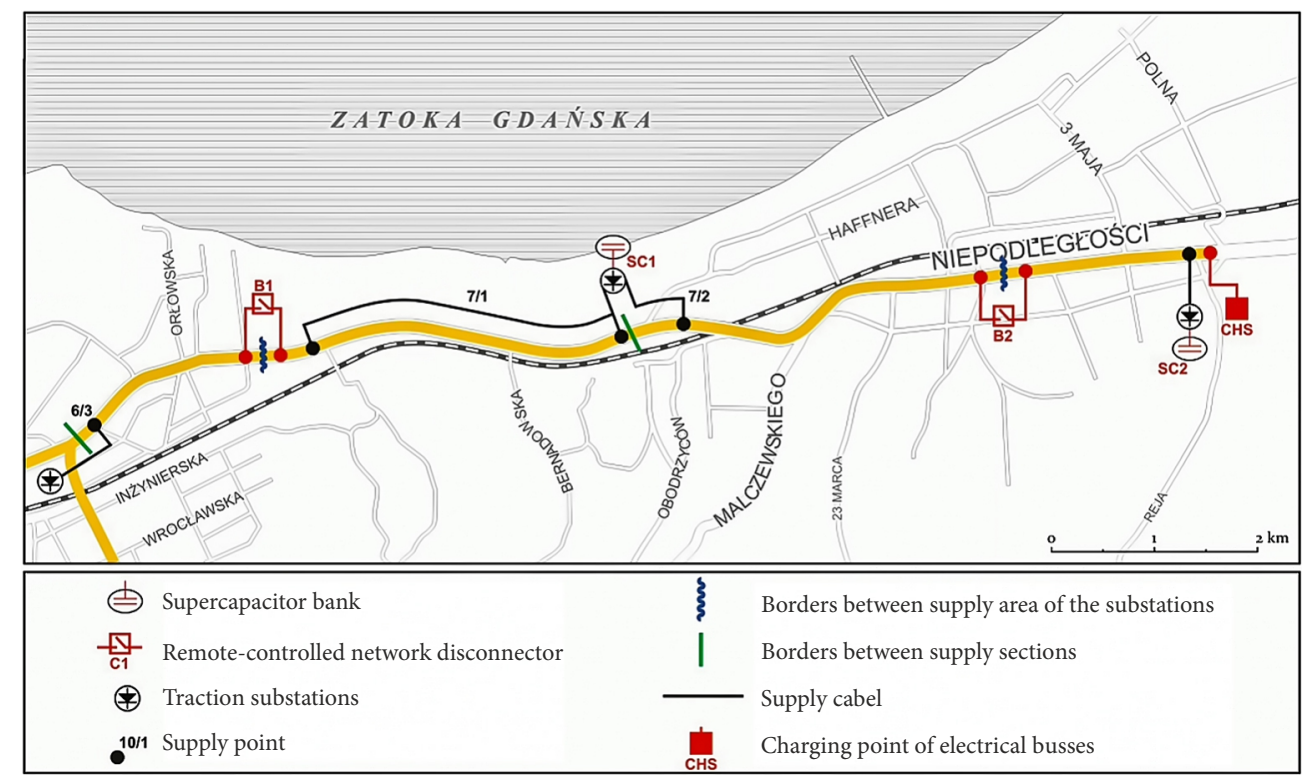

Figure 6. Supply system for trolleybus network in the area of Sopot, with the following Smart Grid elements marked: charging point for electric buses (CHS) supplied from the trolleybus contact line and bilateral supply connection (B); the inverter is not shown 
there is always a bus connected to the charging point, is the most advantageous one, as there is a possibility to collect recuperation energy at all times. Taking into consideration the fact that the assumed charging time is $15 \mathrm{~min}$, electric buses should be running every $15 \mathrm{~min}$. In practice it is necessary to allow for lower frequency of bus service, which means that for most of the time the charging point would not be used and it would not be possible to collect recuperation energy. This is why two additional options of electric bus service, with the frequency of every $30 \mathrm{~min}$ and every hour, were considered during the simulation. The options included in the analysis were as follows:

- Option 0: Current situation, unilateral supply of the contact line; frequency of trolleybus service - every 15 min;

- Option 1: Introduction of Smart Grid solutions in the form of bilateral supply of the contact line; frequency of trolleybus service - every $15 \mathrm{~min}$;

- Option 2: Introduction of Smart Grid solutions in the form of bilateral supply of the contact line together with a charging point for electric buses; frequency of electric bus service - every hour;

- Option 3: Introduction of Smart Grid solutions; frequency of electric bus service - every hour;
- Option 4: Introduction of Smart Grid solutions; frequency of electric bus service - every hour.

- Option 5: Installation inverter for recuperated energy for using in public building facilities, no electric bus service

- Option 6: Installation inverter for recuperated energy for using in public building facilities, frequency of electric bus service - every hour.

Table 3 presents the comparison of the results of simulation calculations, Figure 8 shows graphic comparison of energy savings in individual options. The increase of recuperation energy use caused by vehicle charging and inverter has been marked.

The influence of voltage levels in the overhead contact line on the extent to which the braking energy recuperation is utilised has also been investigated in the course of research work. Simulation of influence of traction substation busbar voltage on the level of recuperation utilisation has been performed (Figure 3). Figure 9 presents the dependence of energy recuperation in the function of upper value of regenerative braking voltage threshold, whereas Figure 10 shows the influence of the substation no-load voltage.

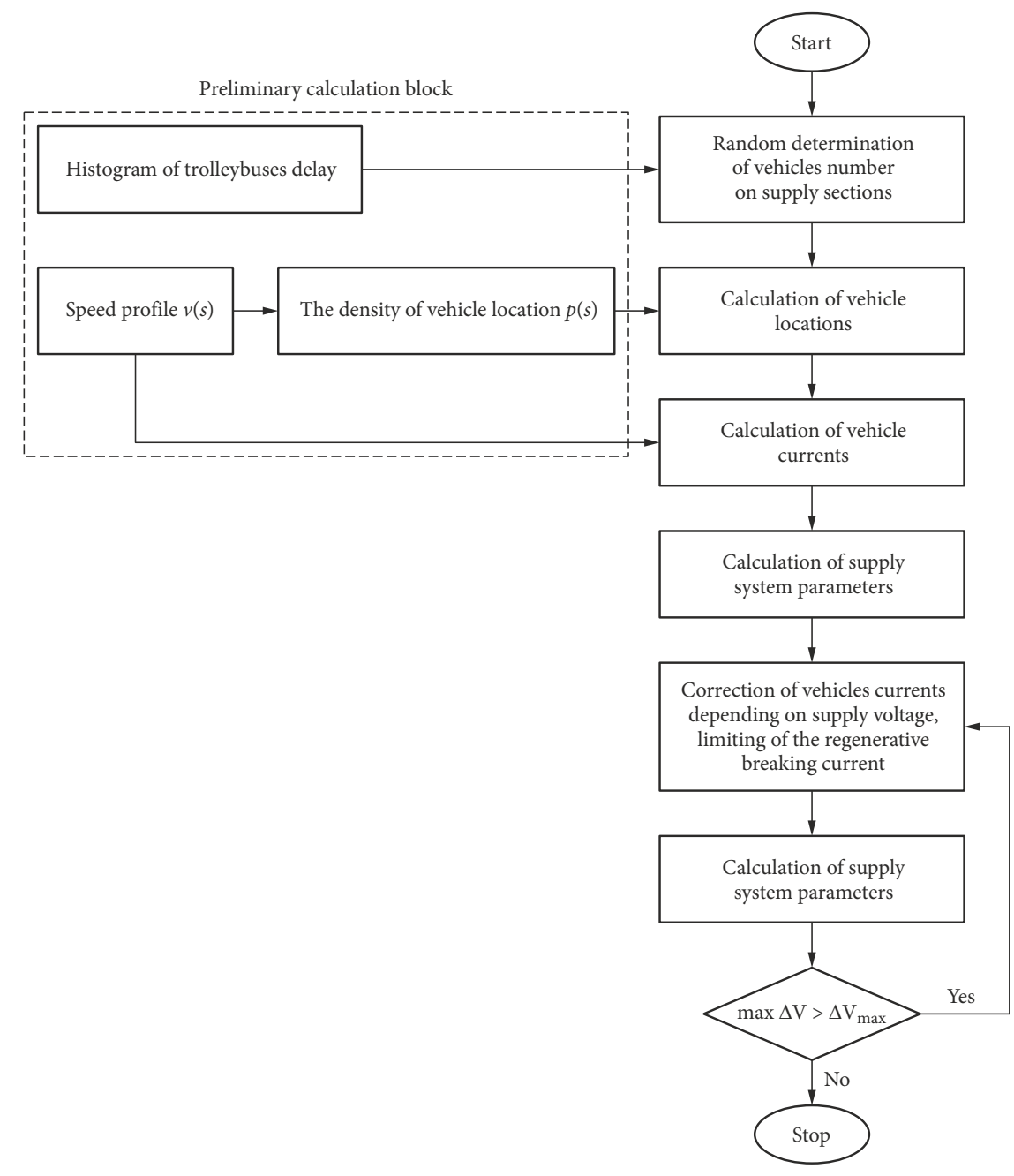

Figure 7. General scheme of the traction power supply system simulation model using the Monte Carlo method 
Table 3. Comparison of trolleybus network supply options

\begin{tabular}{|l|c|c|c|c|c|c|c|}
\hline \multicolumn{1}{|c|}{ Option } & 0 & 1 & 2 & 3 & 4 & 5 & 6 \\
\hline Electric bus charging power [kW] & none & none & 100 & 100 & 100 & none & 100 \\
\hline Frequency of electric bus service $[\mathrm{min}]$ & none & none & 60 & 30 & 15 & none & 15 \\
\hline Inverter for energy recuperation & no & no & no & no & no & yes & yes \\
\hline Consumed power* $[\mathrm{kW}]$ & 56.1 & 53.0 & 49.3 & 45.5 & 41.6 & 44.1 & 40.1 \\
\hline Rate of energy recuperation [\%] & 7.7 & 10.7 & 16.8 & 22.3 & 28.5 & 24.0 & 30.0 \\
\hline
\end{tabular}

Note: ${ }^{\star}$ - without electric bus charging power.

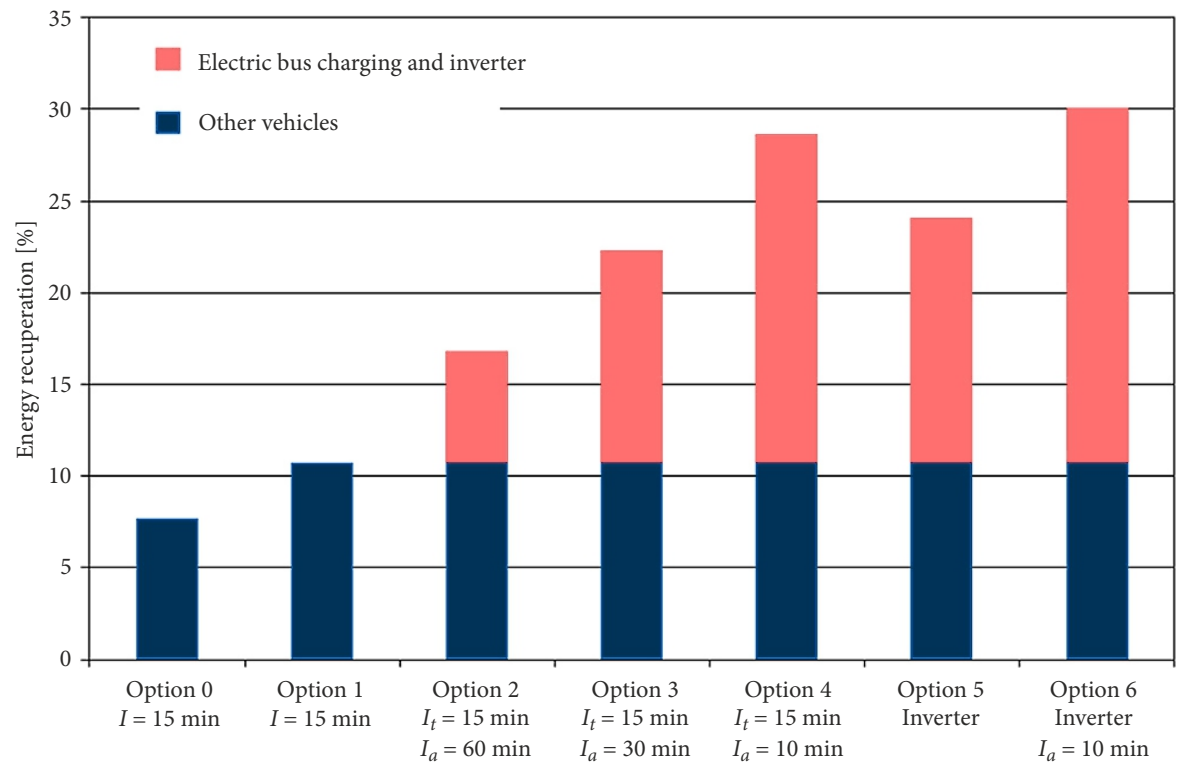

Figure 8. Comparison of energy recuperation in individual options analysed: blue colour - consumption of recuperation energy by other vehicles; red colour - increase of energy recuperation following the installation of electric bus charging point; $I_{t}-$ frequency of trolleybus service; $I_{a}$ - frequency of electric bus service (and charging); inverter - installation of the inverter, using the recovered energy for supply of public building facilities

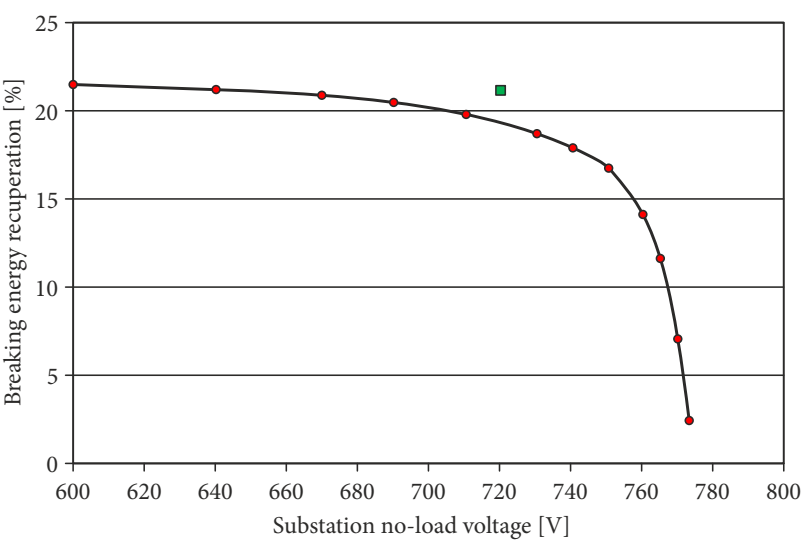

Figure 9. Rate of energy recuperation in the function of traction substation no-load voltage (the green point marks recuperation effectiveness when controlled rectifiers are used)

\section{Discussion}

The conducted research confirmed the justifiability of introducing bilateral supply in overhead contact line. It is true that the utilisation of energy is limited at the level of a few per cent, but the expenses connected with the in-

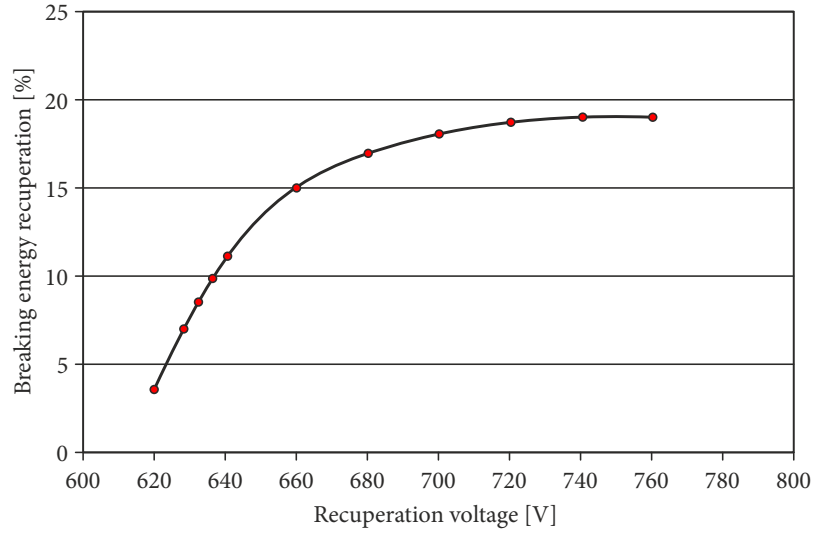

Figure 10. Rate of energy recuperation in the function of upper value of regenerative braking voltage threshold

troduction of bilateral traction supply are small, while its introduction, apart from supply voltage drops, enhances the stability of voltage within the network. Therefore such solution should be applied as often as possible. 
The conducted simulations show that using trolleybus contact line to charge electric buses combined with introduction of bilateral supply of the contact line results in improvement of regenerative braking effectiveness (Table 3, Figure 8). This improvement is most apparent when electric buses are charged continuously, so that it is possible at all times for the recuperation energy to flow to an electric vehicle, in which situation electric buses run with the frequency of $15 \mathrm{~min}$. Then the rate of energy recovery increases from 7.7 to $28.5 \%$, which reduces the total amount of consumed energy by $20 \%$. If the electric bus service is less frequent, there are times when it is not possible to use the generated recuperation energy for charging. When a charging point is not fully utilised, it brings about a decrease in the use of recuperation energy and, consequently, fewer energy benefits derived from the integration of electric bus and trolleybus power systems. Reducing the frequency of bus service to every $30 \mathrm{~min}$ results in the decrease of energy recovery from 28.5 to $22.3 \%$, while in the situation when buses run every hour, the rate of energy recovery is $16.8 \%$, so energy savings are hardly noticeable.

It is worth emphasising that recuperation energy can be utilised for the purpose of supplying, for example, public buildings. The consumption of energy at the level of $30 \ldots .50 \mathrm{~kW}$ allows for considerable increase of recuperation energy utilisation within the trolleybus network. This creates a possibility for implementation of Smart Grid intelligent network technology at a relatively small expense.

Selection of appropriate idling voltage for traction substations and vehicle recuperation voltage is also important. It allows for increase of energy recuperation by $2 . .3 \%$. However, in extreme situations, where voltage thresholds are improperly set, this increase can be much higher (Figure 9).

\section{Conclusions}

The article presents introduction of the following Smart Grid tools:

- bilateral supply of overhead catenary;

- charging station for electric buses;

- using the recuperated energy for supply building facilities.

The synergy of these solutions allows for the increase of energy recovery, with small financial investments.

A key element in determining the effective use of recuperation is the topology of the traction catenary. In the case of supply areas with a significant number of vehicles, i.e. with high traffic volume or high intensity, the use of braking energy in the vehicle - vehicle path is very visible, which removes the need for additional devices absorbing recovery energy, such as supercapacitor banks or substation inverters. The failure to use recuperation energy occurs in areas with low traffic.

Accordingly, to increase the use of energy recovery, at first it is necessary to consider the possibility of reconfig- uring the supply system, which will facilitate the flow of braking energy. In many situations, very good results can be achieved at a low cost. Small substation power supply areas galvanically isolated from the rest of the network should be avoided. Supply areas of such substations should be interconnected to create the largest area of recuperation energy flow.

Therefore, it is recommended to introduce bilateral supply of the overhead line to allow for an increase in the utilization rate of recuperation and reduction of transmission losses. Bilateral power supply may be used both in central and decentralized power supply systems. Examples of bilateral power supply solutions were presented in the previous section of the article. The power supply system designed taking into account the flow of recuperation energy is able to accept the vast majority of the recovered energy. The use of banks is appropriate in the areas of the overhead line of a specific nature, i.e. in mountainous areas or areas of unusual traffic distribution.

Charging stations for electric buses constitute an important element, which could improve the use of recuperation energy. Electric buses have become an increasingly popular means of transport in the cities; however, their charging poses a problem. It requires the construction of charging stations, which is related to the need of preparing appropriate infrastructure, whose main element is the transformer stations for bus charging points. To this end, an overhead line for a tram or trolleybus transport can be used, which has many advantages. In such a case, the existing infrastructure may be used, so there is no need to build additional transformer stations. In addition, the charging stations for electric buses are an alternative for the banks of recuperation energy, which solution requires only minor capital expenditures. Currently, hubs integrating many means of municipal transport, such as buses, trams, trolleybuses and trains are built. Such hubs may also be used for integration of power systems. Those places are characterised by common braking of vehicles, which results in a significant amount of generated recuperation energy. As indicated by the measurement tests, recuperation is most intense in locations of frequent starting and stopping. Therefore, in these places it is reasonable to build electricity charging points.

Utilisation of recuperation energy for one's own, diversified needs constitutes an alternative for using energy storage devices or high-power substation inverters. Energy storage devices are connected with considerable expenses and a long time of investment return, while common use of substation inverters is not very likely due to the lack of interest on the part of operators of distribution systems. Smart Grid solutions, in particular the consumption of recuperation energy by numerous low-power receivers, such as charging stations for electric vehicles, or by buildings for their own needs, constitutes a low-cost alternative for expensive technical solutions. 


\section{Acknowledgements}

This paper has been elaborated in the framework of the project ELIPTIC "Electrification of public transport in cities" co-financed by the European Union's Horizon 2020 research and innovation programme under the grant agreement No 636012.

\section{References}

Altmann, M.; Elschner, K. 2009. Energy efficiency of traction power supply within the EU project Railenergy, Elektrische Bahnen 107(4-5): 184-191.

Angrisani, G.; Canelli, M.; Roselli, C.; Sasso, M. 2015. Integration between electric vehicle charging and micro-cogeneration system, Energy Conversion and Management 98: 115-126. https://doi.org/10.1016/j.enconman.2015.03.085

Bartłomiejczyk, M.; Połom, M. 2017. The impact of the overhead line's power supply system spatial differentiation on the energy consumption of trolleybus transport: planning and economic aspects, Transport 32(1): 1-12. https://doi.org/10.3846/16484142.2015.1101611

Bartłomiejczyk, M.; Połom, M. 2016. Multiaspect measurement analysis of breaking energy recovery, Energy Conversion and Management 127: 35-42. https://doi.org/10.1016/j.enconman.2016.08.089

Cornic, D. 2010. Efficient recovery of braking energy through a reversible DC substation, in Electrical Systems for Aircraft, Railway and Ship Propulsion, 19-21 October 2010, Bologna, Italy, 1-9. https://doi.org/10.1109/ESARS.2010.5665264

Díez, A. E.; Díez, I. C.; Lopera J. A.; Bohorquez, A.; Velandia, E.; Albarracin, A.; Restrepo, M. 2012. Trolleybuses in Smart Grids as effective strategy to reduce greenhouse emissions, in 2012 IEEE International Electric Vehicle Conference, 4-8 March 2012, Greenville, SC, US, 1-6. https://doi.org/10.1109/IEVC.2012.6183213

Falvo, M. C.; Lamedica, R.; Bartoni, R.; Maranzano, G. 2011. Energy management in metro-transit systems: An innovative proposal toward an integrated and sustainable urban mobility system including plug-in electric vehicles, Electric Power Systems Research 81(12): 2127-2138. https://doi.org/10.1016/j.epsr.2011.08.004

Frilli, A.; Meli, E.; Nocciolini, D.; Pugi, L.; Rindi, A. 2016. Energetic optimization of regenerative braking for high speed railway systems, Energy Conversion and Management 129: 200-215. https://doi.org/10.1016/j.enconman.2016.10.011

Glotz-Richter, M.; Koch, H. 2016. Electrification of public transport in cities (Horizon 2020 ELIPTIC Project), Transportation Research Procedia 14: 2614-2619.

https://doi.org/10.1016/j.trpro.2016.05.416

González-Gil, A.; Palacin, R.; Batty, P. 2013. Sustainable urban rail systems: Strategies and technologies for optimal management of regenerative braking energy, Energy Conversion and Management 75: 374-388.

https://doi.org/10.1016/j.enconman.2013.06.039

González-Gil, A.; Palacin, R.; Batty, P.; Powell, J. P. 2014. A systems approach to reduce urban rail energy consumption, Energy Conversion and Management 80: 509-524. https://doi.org/10.1016/j.enconman.2014.01.060

Hamacek, Š.; Bartłomiejczyk, M.; Hrbáč, R.; Mišák, S.; Stýskala, V. 2014. Energy recovery effectiveness in trolleybus transport, Electric Power Systems Research 112: 1-11.

https://doi.org/10.1016/j.epsr.2014.03.001
Hewings, D.; Palfreyman, T. 2013. Application of the smart grid to railway traction systems - vision and realisation, Elektrische Bahnen 111(6-7): 360-367.

Hrbac, R.; Kolar, V.; Mlcak, T. 2015. Distributed measurement system with GPS synchronisation and its use in electric traction, Elektronika ir elektrotechnika 21(6): 8-13.

https://doi.org/10.5755/j01.eee.21.6.13750

Jarzebowicz, L.; Karwowski, K.; Kulesza, W. J. 2017. Sensorless algorithm for sustaining controllability of IPMSM drive in electric vehicle after resolver fault, Control Engineering Practice 58: 117-126.

https://doi.org/10.1016/j.conengprac.2016.10.004

Judek, S.; Skibicki, J. 2009. Wyznaczanie parametrów elektrycznych trakcyjnego układu zasilania dla złożonych warunków ruchu przy wykorzystaniu programu PSpice, Przegląd Elektrotechniczny 85(12): 270-273. (in Polish).

Jiang, Y.; Liu, J.; Tian, W.; Shahidehpour, M.; Krishnamurthy, M. 2014. Energy harvesting for the electrification of railway stations: getting a charge from the regenerative braking of trains, IEEE Electrification Magazine 2 (3): 39-48. https://doi.org/10.1109/MELE.2014.2333561

Kolář, V.; Hrbáč, R.; Fukala, B. 2012. Zatížení trakční transformovny v závislosti na jízdě vlaků, 13th International Scientific Conference on Electric Power Engineering (EPE), 23-25 May 2012, Brno, Czech Republic, 1001-1004. (in Czech).

Kulesz, B. 2005. Rectifier transformers in electric traction substations - different designs, Transport 20(2): 66-72.

Nasr, S.; Iordache, M.; Petit, M. 2014. Smart micro-grid integration in DC railway systems, in IEEE PES Innovative Smart Grid Technologies, Europe, 12-15 October 2014, Istanbul, Turkey, 1-6. https://doi.org/10.1109/ISGTEurope.2014.7028913

Nicolau, M. S.; López, J.; Tapia, S.; Mera, J. M. 2018. Expert system using multi-objective optimization of the direct current railway power supply system, Transport 33(1): 131-142. https://doi.org/10.3846/16484142.2015.1108225

Niemann, T.; Nölkensmeier, S.; Steinbauer, J.; Schirmer, G. 2007. Pilotanwendung des kombinierten Schutz- und Steuergerat Siträs PRO bei der VAG Nürnberg, Elektrische Bahnen 105(3): 156-163. (in German).

Pearre, N. S.; Swan, L. G. 2016. Electric vehicle charging to support renewable energy integration in a capacity constrained electricity grid, Energy Conversion and Management 109: 130-139. https://doi.org/10.1016/j.enconman.2015.11.066

Połom, M.; Bartłomiejczyk, M. 2011. Trolleybusses in the city of Gdynia. A historical and geographical study, in: M. Bartłomiejczyk, M. Połom (Eds.). Determinants of Functioning of Trolleybus Transport in Selected Cities of the European Union, 119-139.

Połom, M.; Palmowski, T. 2009. Rozwój i funkcjonowanie komunikacji trolejbusowej w Gdyni, Pelplin, 152 s. (in Polish).

Tuballa, M. L.; Abundo, M. L. 2016. A review of the development of smart grid technologies, Renewable and Sustainable Energy Reviews 59: 710-725. https://doi.org/10.1016/j.rser.2016.01.011 